\title{
PEMETAAN DAERAH RAWAN BANJIR (STUDI KASUS: BANJIR PACITAN DESEMBER 2017)
}

\author{
Muhammad Taufik ${ }^{1}$, Irhasy Wifie Rahman ${ }^{2}$ \\ 1,2Departemen Teknik Geomatika, FTSLK-ITS, Kampus ITS Sukolilo, Surabaya, 60111, Indonesia \\ e-mail: ${ }^{1}$ taufik_m@geodesy.its.ac.id, ${ }^{2}$ wifi.itsme@gmail.com
}

\begin{abstract}
Abstrak
Setiap tahun bencana alam terjadi di berbagai tempat di wilayah Indonesia. Menurut Data Informasi Bencana Indonesia (DIBI)-BNPB, lebih dari 78\% kejadian merupakan bencana hidrometeorologi. Kejadian bencana hidrometeorologi merupakan kelompok kejadian bencana banjir, gelombang ekstrim dan cuaca esktrim. Curah hujan merupakan fenomena yang sudah biasa mengingat lokasi Indonesia yang berada di daerah tropis. Wilayah satu dengan yang lain dapat memiliki faktor penyebab banjir yang berbeda. Analisa multi-kriteria dapat digunakan untuk melihat kriteria spesifik dari penyebab banjir di suatu wilayah. Tujuan yang ingin dicapai dalam penelitian ini adalah Penyusunan basis data penyebab banjir yang kemudian digunakan unuk membuat Peta daerah rawan banjir kabupaten Pacitan. Peta daerah rawan banjir di hasilkan dari overlay dari parameter curah hujan, jenis tanah, kerapatan aliran,tutupan lahan, ketinggian dan kemiringan lereng yang kemudian dilakukan skoring dan pembobotan menggunakan metode CMA (Composite Mapping Analysis). Dari hasil pengolahan didapatkan peta daerah rawan banjir dengan luas daerah rawan banjir yang dibagi menjadi 3 kelas, yaitu kelas tidak rawan dengan luas daerah 61.879 ha (44\%), kelas rawan dengan luas daerah 67.885 ha (48\%) dan kelas sangat rawan dengan luas daerah 11.144 ha (8\%).
\end{abstract}

Kata kunci : Daerah Rawan Banjir, SIG, Composite Mapping Analysis

\begin{abstract}
Every year natural disasters occur in various places in the territory of Indonesia. According to the Indonesian Disaster Information Data (DIBI) -BNPB, more than $78 \%$ of the events were hydrometeorological disasters. Hydrometeorological disasters are groups of floods, extreme waves and extreme weather events. Rainfall is a phenomenon that is familiar considering Indonesia's location in the tropics. One area to another can have different causes of flooding. Multi-criteria analysis can be used to see the specific criteria of the cause of flooding in an area. The objective to be achieved in this research is to compile a database that causes floods which are then used to create a map of flood-prone areas in Pacitan district. Maps of flood-prone areas are generated from overlays of parameters of rainfall, soil type, flow density, land cover, height and slope which are then scored and weighted using the CMA (Composite Mapping Analysis) method. From the processing results obtained flood-prone areas map which are divided into 3 classes, namely non-prone classes with an area of 61.879 ha (44\%), prone classes with an area of 67.885 ha (48\%) and very vulnerable classes with an area of 11.144 ha (8\%).
\end{abstract}

Keywords : Flood prone areas, GIS, Composite Mapping Analysis 


\section{PENDAHULUAN}

Setiap tahun bencana alam terjadi di berbagai tempat di wilayah Indonesia. Menurut data yang dihimpun dalam Data Informasi Bencana Indonesia (DIBI)-BNPB, terdapat lebih dari 1.800 kejadian bencana pada periode tahun 2005 hingga 2015 dan lebih dari $78 \%$ (11.648) kejadian merupakan bencana hidrometeorologi sedangkan hanya sekitar $22 \%$ (3.810) yang merupakan bencana geologi. Kejadian bencana hidrometeorologi merupakan kelompok kejadian bencana banjir, gelombang ekstrim, kebakaran lahan dan hutan, kekeringan, dan cuaca esktrim (Amri dkk. 2016). Cuaca ekstrem yang terjadi akibat pengaruh Siklon Tropis Cempaka menjadi salah satu faktor utama terjadinya banjir di beberapa wilayah di Jawa Timur dan Jawa Tengah. Siklon ini menyebabkan curah hujan di dua daerah begitu tinggi mencapai 286 $\mathrm{mm} /$ hari di Yogyakarta dan $383 \mathrm{~mm} /$ hari di Pacitan (BNPB 2017). Dampak dari siklon ini memang cukup besar, tercatat ada sekitar 28 kabupaten/kota dan 41 orang meninggal dunia akibat banjir dan tanah longsor yang terjadi. Kabupaten yang paling parah terdampak adalah Pacitan. Banjir dan longsor yang terjadi sempat menyebabkan akses jalan ke kabupaten ini terputus total. Korban meninggal di Pacitan menyentuh angka 25 orang, 6 orang meninggal karena banjir dan 19 orang karena tanah longsor (BNPB 2017).

Curah hujan yang tinggi merupakan fenomena yang sudah biasa mengingat lokasi Indonesia yang berada di daerah tropis. Faktor lain yang bisa menjadi pemicu banjir adalah perubahan lahan di daerah hulu seperti pembabatan hutan dan perkembangan wilayah perkotaan yang sangat cepat. Wilayah satu dengan yang lain dapat memiliki faktor-faktor penyebab banjir yang berbeda. Analisa multi-kriteria dapat digunakan untuk melihat kriteria spesifik dari penyebab banjir di suatu wilayah (Haryani dkk. 2012). Bobot dari setiap parameter penyebab banjir berbeda pada setiap wilayah, CMA (Composite Mapping Analysis) digunakan untuk penentuan bobot setiap parameter banjir (Suratijaya 2007).

Pada penelitian ini metode MCE (Multicriteria Evaluation) atau Analisa multikriteria akan digunakan untuk membuat peta daerah rawan banjir di Kabupaten Pacitan berdasarkan Kejadian Banjir pada Bulan Desember 2017.

\section{METODE}

\section{Lokasi Penelitian}

Lokasi penelitian mengambil studi kasus di Kabupaten Pacitan, Jawa Timur. Secara Geografis, Kabupaten Pacitan memiliki luas sebesar $1.389,8716 \mathrm{Km}^{2}$ dan terletak pada koordinat $7^{\circ} 55^{\prime} 00^{\prime \prime}$ LS - $8^{\circ} 17^{\prime} 00^{\prime \prime}$ LS dan $110^{\circ} 55^{\prime} 00^{\prime \prime}$ BT $-111^{\circ} 25^{\prime} 00^{\prime \prime}$ BT. Batas administrasi Kabupaten Pacitan adalah sebagai berikut :

Utara: Kabupaten Ponorogo

Timur: Kabupaten Trenggalek

Selatan: Samudra Hindia

Barat: Kabupaten Wonogiri (Jawa Tengah)

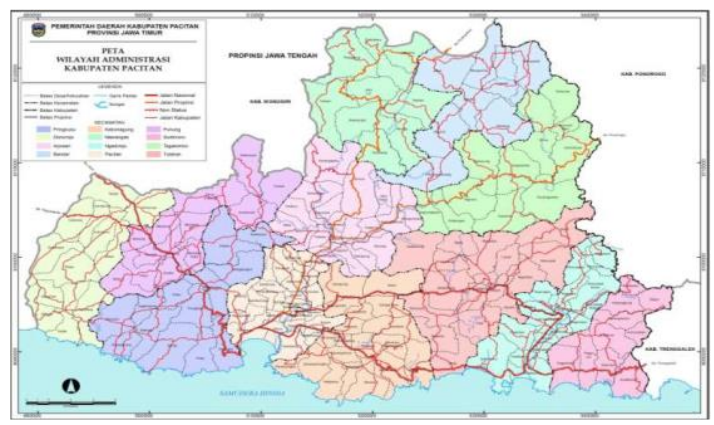

Gambar 1. Peta Administrasi Kabupaten Pacitan (Sumber : repository.umy.ac.id)

\section{Data dan Peralatan}

- Data

Data yang diperlukan dalam penelitian ini merupakan data sekunder dengan rincian sebagai berikut :

a. Citra landsat 8 OLI/TIRS tanggal perekaman 14 Juli 2017

b. Data curah hujan bulan Desember 2017

c. DEM SRTM resolusi $30 \mathrm{~m}$

d. Peta tanah semi detail kabupaten pacitan 2016

e. DAS kabupaten pacitan

f. Data kejadian banjir di kabupaten pacitan tahun 2007-2017

g. Peta RBI kabupaten pacitan

- Peralatan

Adapun peralatan yang digunakan dalam penelitian ini adalah :

a. Sistem Operasi Windows 7 Home Basic 32Bit

b. ArcGIS 10.4 untuk mengolah data Curah hujan, DEM SRTM, Peta Tanah, DAS Kabupaten Pacitan.

c. ENVI 5.1 untuk mengolah Citra Landsat 8 


\section{Pengolahan Data}

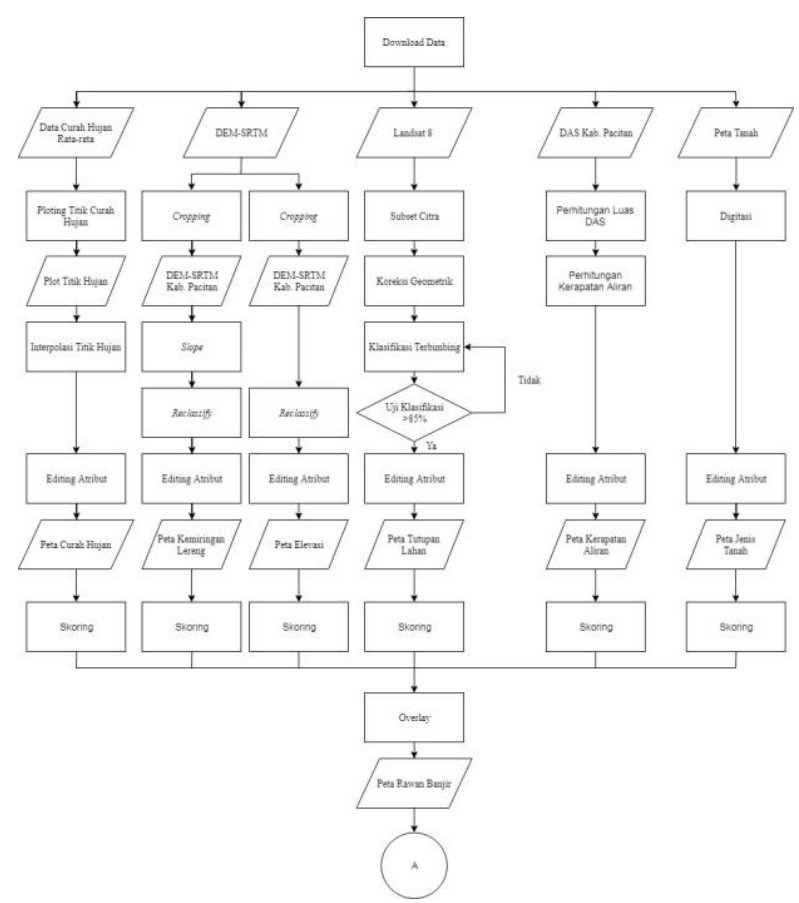

Gambar 2. Diagram Alir Pengolahan Data

\section{HASIL DAN PEMBAHASAN}

\section{Parameter Curah Hujan}

Pengolahan Peta Curah hujan didapatkan dari pengolahan data curah hujan bulan Desember 2017.

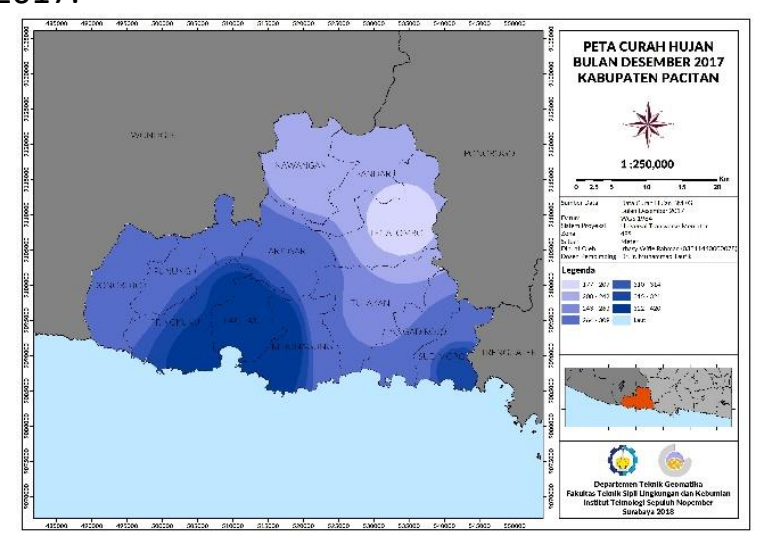

Gambar 3. Peta Curah Hujan

Tabel 1. Klasifikasi Parameter Curah Hujan

\begin{tabular}{|c|c|c|c|c|}
\hline Klasifikasi & Skor & Kelas & $\begin{array}{c}\text { Luas } \\
\text { Daerah } \\
\text { (Ha) }\end{array}$ & Prosentase \\
\hline$>150$ & 5 & Tinggi & 141.757 & $100 \%$ \\
\hline $76-150$ & 4 & $\begin{array}{l}\text { Agak } \\
\text { Tinggi }\end{array}$ & - & $0 \%$ \\
\hline $41-75$ & 3 & Sedang & - & $0 \%$ \\
\hline $21-40$ & 2 & $\begin{array}{c}\text { Agak } \\
\text { Rendah }\end{array}$ & - & $0 \%$ \\
\hline$<20$ & 1 & Rendah & - & $0 \%$ \\
\hline
\end{tabular}

Parameter Curah hujan di kabupaten Pacitan dibagi menjadi 5 kelas kerawanan, yaitu tinggi, agak tinggi, sedang, agak rendah, dan rendah. Hasil dari analisa peta tutupan lahan didapatkan semua klasifikasi masuk dalam kelas Tinggi.

\section{Parameter Kemiringan Lereng}

Pengolahan Peta Kemiringan Lereng didapatkan dari pengolahan data SRTM (Shuttle Radar Topography Mission) Kabupaten Pacitan.

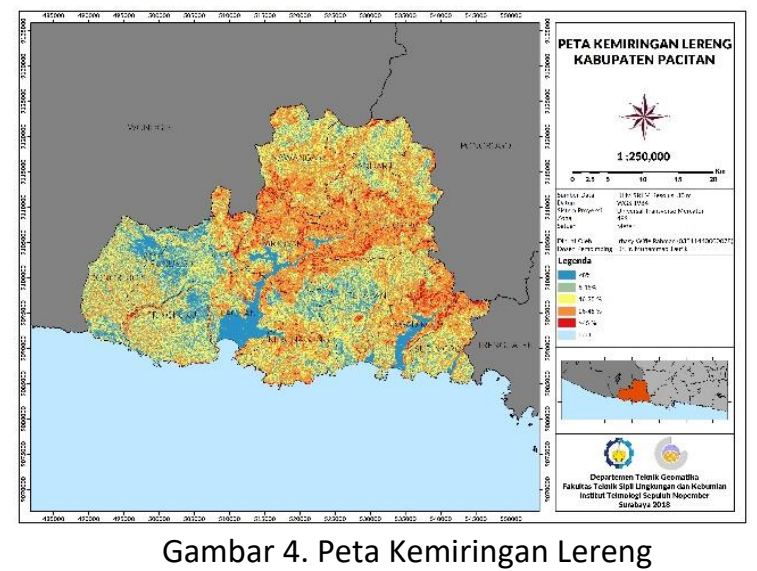

Parameter Kemiringan Lereng di kabupaten Pacitan dibagi menjadi 5 kelas kerawanan, yaitu tinggi, agak tinggi, sedang, agak rendah, dan rendah. Hasil dari analisa peta kemiringan lereng didapatkan kurang dari $50 \%$ wilayah di kabupaten pacitan yang termasuk dalam kelas kerawanan Tinggi dan agak tinggi. Kelas Kerawanan Tinggi sebagian besar terdapat di wilayah kecamatan pacitan, punung, pringkuku, arjosari, tulakan dan kecamatan ngadirojo.

Tabel 2. Klasifikasi Parameter Kemiringan Lereng

\begin{tabular}{lllll}
\hline Klasifikasi & Skor & Kelas & $\begin{array}{l}\text { Luas } \\
\text { Daerah } \\
\text { (Ha) }\end{array}$ & Prosentase \\
\hline$<8 \%$ & 5 & Tinggi & 19.293 & $14 \%$ \\
$8-15 \%$ & 4 & $\begin{array}{l}\text { Agak } \\
\text { Tinggi }\end{array}$ & 26.961 & $19 \%$ \\
$16-25 \%$ & 3 & Sedang & 43.233 & $30 \%$ \\
$26-45 \%$ & 2 & $\begin{array}{l}\text { Agak } \\
\text { Rendah }\end{array}$ & 46.429 & $33 \%$ \\
& & $\begin{array}{l}\text { Rendah } \\
\text { R }\end{array}$ & 5.815 & $4 \%$ \\
\hline
\end{tabular}

\section{Parameter Ketinggian}

Pengolahan Peta Ketinggian didapatkan dari pengolahan data SRTM (Shuttle Radar Topography Mission) Kabupaten Pacitan. 


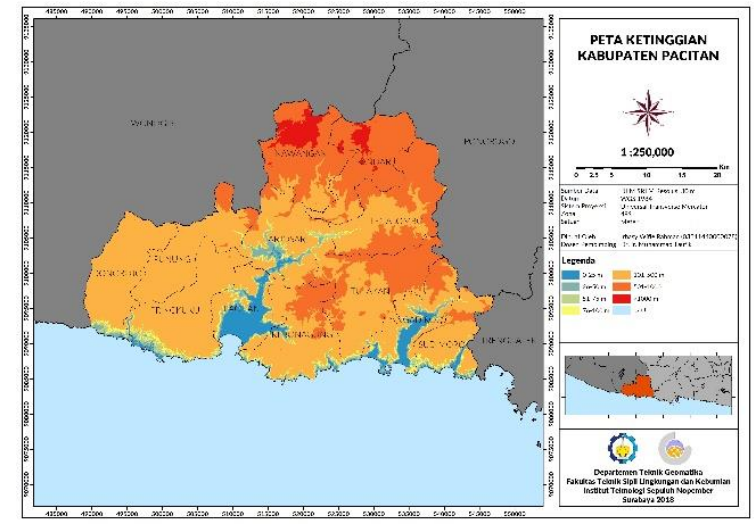

Gambar 5. Peta Ketinggian

Parameter ketinggian di kabupaten Pacitan dibagi menjadi 5 kelas kerawanan, yaitu tinggi, agak tinggi, sedang, agak rendah, dan rendah. Hasil dari analisa peta ketinggian didapatkan $88 \%$ wilayah di kabupaten pacitan yang termasuk dalam kelas kerawanan rendah. Kelas kerawanan tinggi sebagian besar terdapat di wilayah kecamatan pacitan, arjosari, dan kecamatan ngadirojo.

Tabel 3. Klasifikasi Parameter Ketinggian

\begin{tabular}{|c|c|c|c|c|}
\hline Klasifikasi & Skor & Kelas & $\begin{array}{c}\text { Luas } \\
\text { Daerah } \\
\text { (Ha) }\end{array}$ & Prosentase \\
\hline $0-25 \mathrm{~m}$ & 5 & Tinggi & 6.193 & $4 \%$ \\
\hline $26-50 \mathrm{~m}$ & 4 & $\begin{array}{l}\text { Agak } \\
\text { Tinggi }\end{array}$ & 3.539 & $3 \%$ \\
\hline $51-75 \mathrm{~m}$ & 3 & Sedang & 3.507 & $2 \%$ \\
\hline $75-100 \mathrm{~m}$ & 2 & $\begin{array}{c}\text { Agak } \\
\text { Rendah }\end{array}$ & 3.534 & $3 \%$ \\
\hline$>100 \mathrm{~m}$ & 1 & Rendah & 124.967 & $88 \%$ \\
\hline
\end{tabular}

\section{Parameter Tutupan Lahan}

Pengolahan Peta Tutupan lahan didapatkan dari pengolahan data Citra Landsat 8 OLI/TIRS tanggal perekaman 14 Juli 2017.

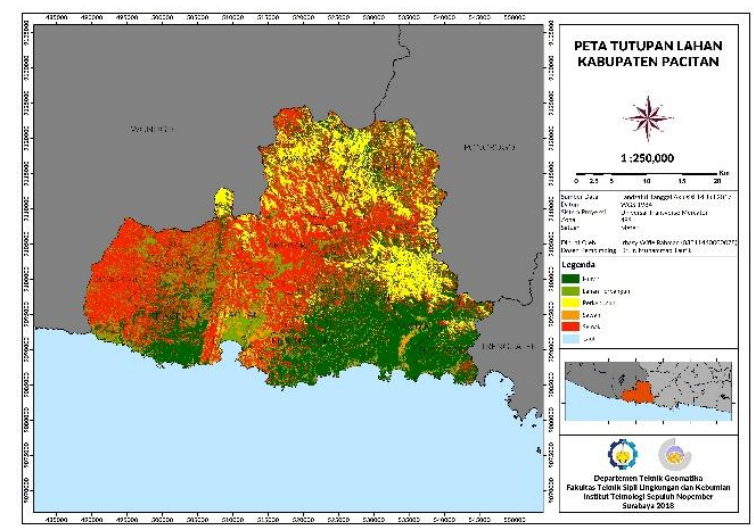

Gambar 6. Peta Tutupan Lahan
Parameter Tutupan Lahan di kabupaten Pacitan dibagi menjadi 5 kelas kerawanan, yaitu tinggi, agak tinggi, sedang, agak rendah, dan rendah. Hasil dari analisa peta tutupan lahan didapatkan kurang dari $50 \%$ wilayah di kabupaten pacitan yang termasuk dalam kelas kerawanan Tinggi dan agak tinggi terdapat di wilayah kecamatan pacitan, punung, pringkuku, dan kecamatan donorojo.

Tabel 4. Klasifikasi Parameter Tutupan Lahan

\begin{tabular}{|c|c|c|c|c|}
\hline Klasifikasi & Skor & Kelas & $\begin{array}{c}\text { Luas } \\
\text { Daerah } \\
\text { (Ha) }\end{array}$ & Prosentase \\
\hline $\begin{array}{l}\text { Lahan } \\
\text { Terbangun }\end{array}$ & 5 & Tinggi & 17.217 & $12 \%$ \\
\hline Sawah & 4 & $\begin{array}{l}\text { Agak } \\
\text { Tinggi }\end{array}$ & 4.170 & $3 \%$ \\
\hline Semak & 3 & Sedang & 55.773 & $39 \%$ \\
\hline Perkebunan & 2 & $\begin{array}{c}\text { Agak } \\
\text { Rendah }\end{array}$ & 23.023 & $16 \%$ \\
\hline Hutan & 1 & Rendah & 41.647 & $30 \%$ \\
\hline
\end{tabular}

\section{Parameter Kerapatan Aliran}

Pengolahan Peta Kerapatan Aliran didapatkan dari pengolahan data DAS dan digitasi sungai dari peta $\mathrm{RBI}$.

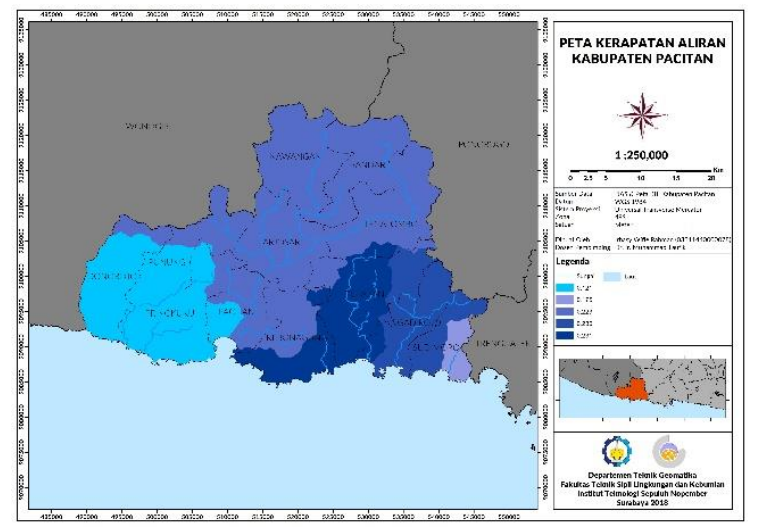

Gambar 7. Peta Kerapatan Aliran

Tabel 5. Klasifikasi Parameter Kerapatan Aliran

\begin{tabular}{lcccc}
\hline Klasifikasi & Skor & Kelas & $\begin{array}{c}\text { Luas } \\
\text { Daerah } \\
\text { (Ha) }\end{array}$ & Prosentase \\
\hline $\begin{array}{l}\text { Sangat } \\
\text { Jarang }\end{array}$ & 5 & Tinggi & - & - \\
Jarang & 4 & $\begin{array}{c}\text { Agak } \\
\text { Tinggi }\end{array}$ & 68.314 & $48 \%$ \\
$\begin{array}{l}\text { Sedang } \\
\text { Rapat }\end{array}$ & 3 & $\begin{array}{c}\text { Sedang } \\
\text { Agak }\end{array}$ & 73.135 & $52 \%$ \\
$\begin{array}{l}\text { Sendah } \\
\text { Rapat }\end{array}$ & 1 & - & - \\
\hline
\end{tabular}


Parameter kerapatan aliran di kabupaten Pacitan dibagi menjadi 5 Kelas kerawanan, yaitu tinggi, agak tinggi, sedang, agak rendah, dan rendah.

\section{Parameter Jenis Tanah}

Pengolahan Peta jenis tanah didapatkan dari pengolahan data peta tanah semi detail kabupaten pacitan.

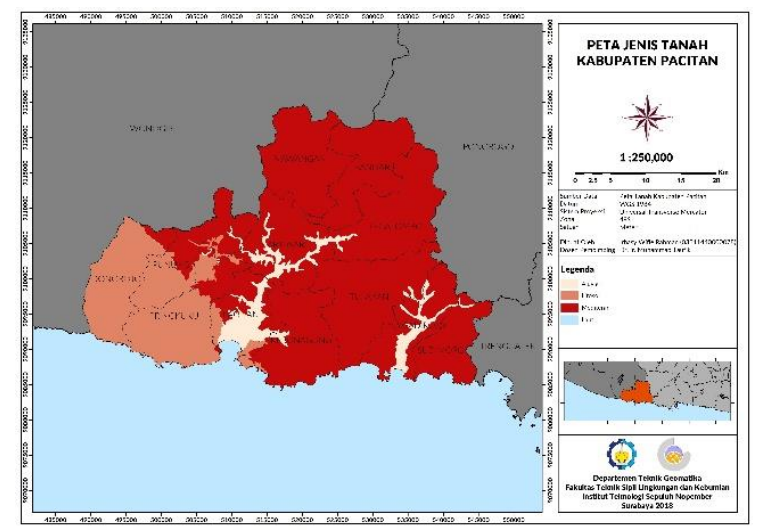

Gambar 8. Peta Jenis Tanah

Parameter jenis tanah di kabupaten Pacitan dibagi menjadi 5 Kelas kerawanan, yaitu tinggi, agak tinggi, sedang, agak rendah, dan rendah.

Tabel 6. Klasifikasi Parameter Jenis Tanah

\begin{tabular}{|c|c|c|c|c|}
\hline Klasifikasi & Skor & Kelas & $\begin{array}{c}\text { Luas } \\
\text { Daerah } \\
\text { (Ha) }\end{array}$ & Prosentase \\
\hline litosol & 5 & Tinggi & 28.467 & $20 \%$ \\
\hline Grumosol & 4 & $\begin{array}{l}\text { Agak } \\
\text { Tinggi }\end{array}$ & - & - \\
\hline Mediteran & 3 & Sedang & 104.914 & $74 \%$ \\
\hline Latosol & 2 & $\begin{array}{c}\text { Agak } \\
\text { Rendah }\end{array}$ & - & - \\
\hline Aluvial & 1 & Rendah & 8.380 & $6 \%$ \\
\hline
\end{tabular}

\section{Penentuan Bobot Parameter Banjir}

Perhitungan Bobot Parameter penyebab banjir dilakukan dengan menggunakan metode CMA. Terdapat 6 parameter penyebab banjir yaitu Parameter Curah Hujan, Parameter Kemiringan Lereng, Parameter Ketinggian, Parameter Tutupan Lahan, Parameter Kerapatan Aliran dan Parameter Jenis Tanah. Tahap pertama melakukan perhitungan bobot menggunakan metode CMA ini adalah melakukan overlay pada 6 parameter penyebab banjir menggunakan software ArcGIS dengan asumsi bobot setara pada setiap parameter, sehingga dihasilkan peta daerah rawan banjir .

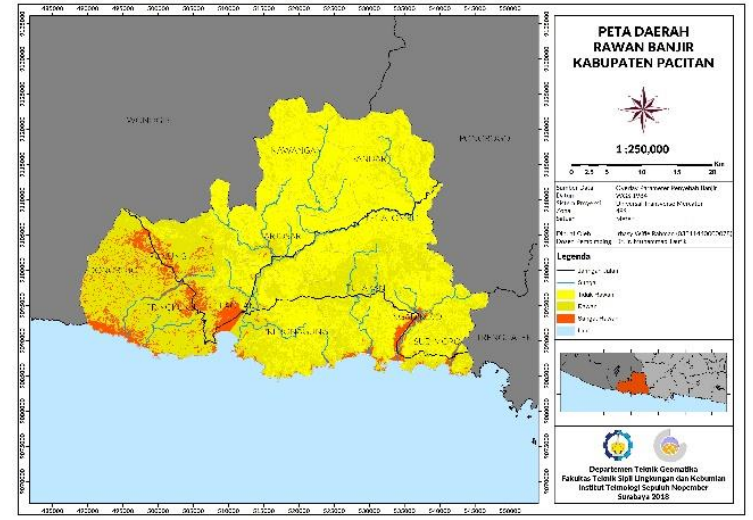

Gambar 9. Peta Daerah Rawan Banjir

Selanjutnya hasil peta daerah rawan banjir di-overlay dengan Peta jumlah kejadian banjir yang didapatkan dari Data kejadian Banjir BNPB tahun 2007 - 2017, dari overlay peta rawan banjir dan peta sebaran kejadian banjir menghasilkan peta potensi kejadian banjir.

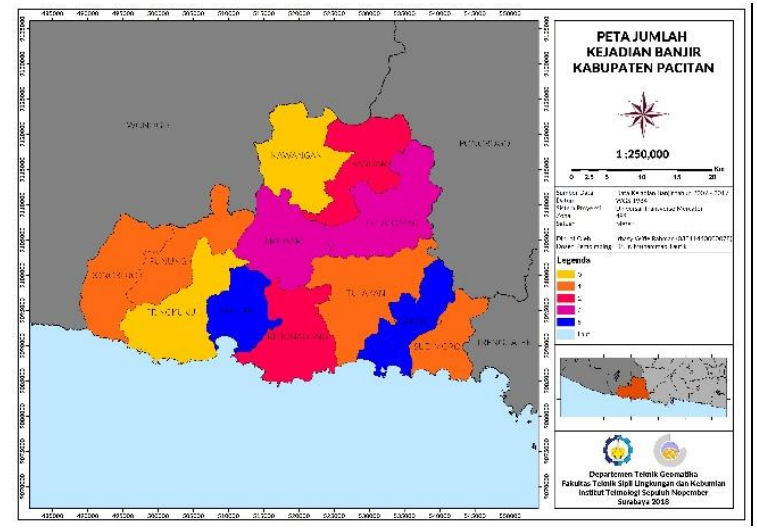

Gambar 10. Peta Jumlah Kejadian Banjir

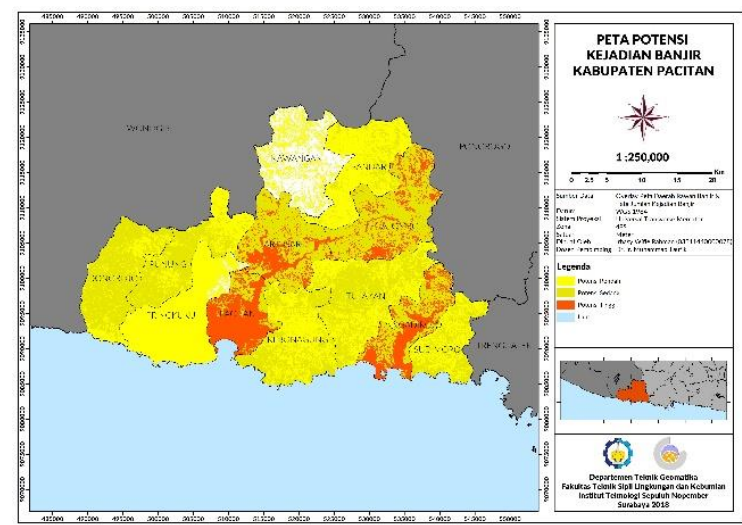

Gambar 11. Peta Potensi Kejadian Banjir

Tahap berikutnya untuk memperoleh bobot parameter penyebab banjir, dilakukan perhitungan mean spatial dari setiap parameter penyebab banjir. Hasil Perhitungan diperoleh mean spatial parameter curah hujan sebesar 0,8456 seperti pada Tabel 7, perhitungan mean spatial 
parameter kemiringan lereng sebesar 0,8117 seperti pada Tabel 8, perhitungan mean spatial parameter ketinggian sebesar 0,8205 seperti pada Tabel 9, perhitungan mean spatial parameter tutupan lahan sebesar 0,8110 seperti pada Tabel 10 , perhitungan mean spatial parameter kerapatan aliran sebesar 0,8342 seperti pada Tabel 11 , dan perhitungan mean spatial parameter jenis tanah sebesar 0,8251 seperti pada Tabel 12.

Tabel 7. Perhitungan Mean Spatial Parameter Curah

\begin{tabular}{lllll}
\multicolumn{5}{c}{ Hujan } \\
$\begin{array}{l}\text { Curah } \\
\text { Hujan }\end{array}$ & $\begin{array}{l}\text { Luas } \\
(\mathrm{Ha})\end{array}$ & $\begin{array}{l}\text { Rawan } \\
\text { Banjir } \\
(\mathrm{Ha})\end{array}$ & $\begin{array}{l}\text { Rasio Rawan } \\
\text { Banjir }\end{array}$ & $\begin{array}{l}\text { Rasio Luas } \\
\text { Rawan } \\
\text { Banjir }\end{array}$ \\
\hline $177-207$ & 8002 & 8002 & 1,0000 & 0,0701 \\
$208-242$ & 31471 & 19465 & 0,6185 & 0,1705 \\
$243-263$ & 14974 & 14146 & 0,9447 & 0,1239 \\
$264-309$ & 51473 & 49674 & 0,9651 & 0,4351 \\
$310-314$ & 6573 & 4411 & 0,6712 & 0,0386 \\
$315-321$ & 8592 & 4420 & 0,5145 & 0,0387 \\
$322-420$ & 19814 & 14058 & 0,7095 & 0,1231 \\
\hline & 140899 & 114177 & Mean Spatial & 0,8456 \\
\hline
\end{tabular}

Tabel 8. Perhitungan Mean Spatial Parameter Kemiringan Lereng

\begin{tabular}{|c|c|c|c|c|}
\hline Kemiringan & $\begin{array}{l}\text { Luas } \\
\text { (Ha) }\end{array}$ & $\begin{array}{l}\text { Rawan } \\
\text { Banjir } \\
(\mathrm{Ha}) \\
\end{array}$ & $\begin{array}{l}\text { Rasio Rawan } \\
\text { Banjir }\end{array}$ & $\begin{array}{l}\text { Rasio Luas } \\
\text { Rawan } \\
\text { Banjir } \\
\end{array}$ \\
\hline$<8 \%$ & 19040 & 15871 & 0,8335 & 0,1390 \\
\hline $8-15 \%$ & 26750 & 20790 & 0,7772 & 0,1821 \\
\hline $16-25 \%$ & 43034 & 33567 & 0,7800 & 0,2940 \\
\hline $26-45 \%$ & 46287 & 38786 & 0,8379 & 0,3397 \\
\hline \multirow[t]{2}{*}{$>45 \%$} & 5788 & 5163 & 0,8921 & 0,0452 \\
\hline & 140899 & 114177 & Mean Spatial & 0,8117 \\
\hline
\end{tabular}

Tabel 9. Perhitungan Mean Spatial Parameter

\begin{tabular}{lllll}
$\begin{array}{l}\text { Ketinggian } \\
(\mathrm{m})\end{array}$ & $\begin{array}{l}\text { Luas } \\
(\mathrm{Ha})\end{array}$ & $\begin{array}{l}\text { Rawan } \\
\text { Banjir } \\
(\mathrm{Ha})\end{array}$ & $\begin{array}{l}\text { Rasio Rawan } \\
\text { Banjir }\end{array}$ & $\begin{array}{l}\text { Rasio Luas } \\
\text { Rawan } \\
\text { Banjir }\end{array}$ \\
\hline $0-25$ & 5866 & 5602 & 0,9550 & 0,0491 \\
$26-50$ & 3450 & 3115 & 0,9029 & 0,0273 \\
$51-75$ & 3482 & 2882 & 0,8278 & 0,0252 \\
$76-100$ & 3527 & 2927 & 0,8297 & 0,0256 \\
$101-500$ & 80557 & 66626 & 0,8271 & 0,5835 \\
$501-1000$ & 40690 & 32118 & 0,7893 & 0,2813 \\
$>1000$ & 3326 & 907 & 0,2727 & 0,0079 \\
\hline & 140899 & 114177 & Mean Spatial & 0,8205 \\
\hline
\end{tabular}

Tabel 10. Perhitungan Mean Spatial Parameter Tutupan

\begin{tabular}{lllll}
\multicolumn{5}{c}{ Lahan } \\
\hline Klasifikasi & $\begin{array}{l}\text { Luas } \\
(\mathrm{Ha})\end{array}$ & $\begin{array}{l}\text { Rawan } \\
\text { Banjir } \\
(\mathrm{Ha})\end{array}$ & $\begin{array}{l}\text { Rasio } \\
\text { Rawan } \\
\text { Banjir }\end{array}$ & $\begin{array}{l}\text { Rasio Luas } \\
\text { Rawan Banjir }\end{array}$ \\
\hline $\begin{array}{l}\text { Hutan } \\
\text { Lahan }\end{array}$ & 41207 & 34363 & 0,8339 & 0,3010 \\
$\begin{array}{l}\text { Terbangun } \\
\text { Perkebunan }\end{array}$ & 17094 & 13656 & 0,7989 & 0,1196 \\
Sawah & 22913 & 17922 & 0,7822 & 0,1570 \\
Semak & 4115 & 3680 & 0,8944 & 0,0322 \\
\hline & 55569 & 44556 & 0,8018 & 0,3902 \\
\hline & 140899 & 114177 & $\begin{array}{l}\text { Mean } \\
\text { Spatial }\end{array}$ & 0,8110 \\
\hline
\end{tabular}

Tabel 11. Perhitungan Mean Spatial Parameter Kerapatan Aliran

\begin{tabular}{lllll}
\multicolumn{5}{c}{ Kerapatan Aliran } \\
\hline $\begin{array}{l}\text { Kerapatan } \\
\text { Aliran }\end{array}$ & $\begin{array}{l}\text { Luas } \\
(\mathrm{Ha})\end{array}$ & $\begin{array}{l}\text { Rawan } \\
\text { Banjir } \\
(\mathrm{Ha})\end{array}$ & $\begin{array}{l}\text { Rasio } \\
\text { Rawan } \\
\text { Banjir }\end{array}$ & $\begin{array}{l}\text { Rasio Luas } \\
\text { Rawan Banjir }\end{array}$ \\
\hline 0.1212 & 29850 & 17854 & 0,5981 & 0,1564 \\
0.1749 & 2761 & 2761 & 1 & 0,0242 \\
0.2232 & 72873 & 58147 & 0,7979 & 0,5093 \\
0.2298 & 16410 & 16410 & 1 & 0,1437 \\
0.2313 & 19005 & 19005 & 1 & 0,1665 \\
\hline & \multirow{2}{*}{140899} & 114177 & $\begin{array}{l}\text { Mean } \\
\text { Spatial }\end{array}$ & 0,8342 \\
\hline
\end{tabular}

Tabel 12. Perhitungan Mean Spatial Parameter Jenis

\begin{tabular}{lllll}
\multicolumn{5}{c}{ Tanah } \\
\hline Jenis Tanah & $\begin{array}{l}\text { Luas } \\
(\mathrm{Ha})\end{array}$ & $\begin{array}{l}\text { Rawan } \\
\text { Banjir } \\
(\mathrm{Ha})\end{array}$ & $\begin{array}{l}\text { Rasio } \\
\text { Rawan } \\
\text { Banjir }\end{array}$ & $\begin{array}{l}\text { Rasio Luas } \\
\text { Rawan Banjir }\end{array}$ \\
\hline Aluvial & 8314 & 8251 & 0,9924 & 0,0723 \\
Litosol & 28233 & 16988 & 0,6017 & 0,1488 \\
Mediteran & 104352 & 88938 & 0,8523 & 0,7790 \\
\hline & 140899 & 114177 & $\begin{array}{l}\text { Mean } \\
\text { Spatial }\end{array}$ & 0,8251 \\
\hline
\end{tabular}

Hasil perhitungan mean spatial selanjutnya digunakan untuk menghitung bobot setiap parameter penyebab banjir, dimana bobot hasil perhitungan dengan metode CMA seperti tercantum pada tabel 13 .

Tabel 13. Perhitungan Bobot Setiap Parameter Penyebab Banjir Dengan Metode CMA

\begin{tabular}{rlll}
\hline No & Parameter & Mean Spatial & Bobot \\
\hline 1 & Kemiringan Lereng & 0,8117 & 16,40 \\
2 & Tutupan Lahan & 0,8110 & 16,39 \\
3 & Jenis Tanah & 0,8251 & 16,68 \\
4 & Kerapatan Aliran & 0,8342 & 16,86 \\
5 & Curah Hujan & 0,8456 & 17,09 \\
6 & Ketinggian & 0,8205 & 16,58 \\
\hline
\end{tabular}




\section{Peta Daerah Rawan Banjir}

Peta Daerah Rawan Banjir didapat dari hasil overlay 6 parameter penyusun banjir mneggunakan bobot hasil perhitungan metode CMA.

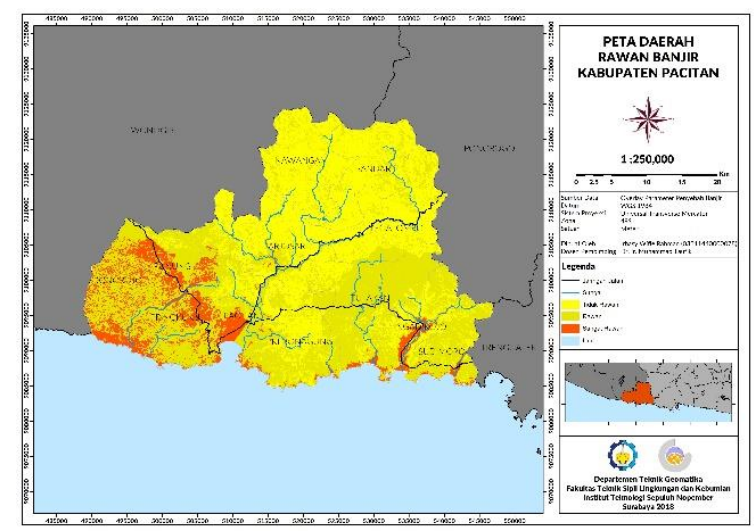

Gambar 12. Peta Daerah Rawan Banjir Metode CMA

Peta daerah rawan banjir di kabupaten Pacitan dibagi menjadi 3 Kelas kerawanan, Tidak rawan, rawan dan sangat rawan. Kelas sangat rawan tersebar di kecamatan pacitan, kecamatan ngadirojo, kecamatan pringkuku, kecamatan punung dan kecamatan donorojo. Kelas rawan tersebar di kecamatan tulakan, kecamatan donorojo, kecamatan pringkuku, kecamatan punung, kecamatan nngadirojo, kecamatan tulakan, kecamatan sudimoro, kecamatan pacitan dan kecamatan kebonagung. Kelas tidak rawan tersebar di kecamatan nawangan, kecamatan bandar, kecamatan tegalombo dan kecamatan arjosari.

Tabel 14. Hasil Analisa Peta Daerah Rawan Banjir

\begin{tabular}{lll}
\hline Klasifikasi & $\begin{array}{l}\text { Luas Daerah } \\
(\mathrm{Ha})\end{array}$ & Prosentase \\
\hline Tidak Rawan & 61.879 & $44 \%$ \\
Rawan & 67.885 & $48 \%$ \\
Sangat Rawan & 11.144 & $8 \%$ \\
\hline
\end{tabular}

\section{Peta Wilayah Banjir Kabupaten Pacitan 2017}

Peta wilayah banjir pacitan didapatkan melalui overlay peta daerah rawan banjir dan data wilayah yang terkena banjir di kabupaten pacitan bulan November dan Desember 2017.

Pada Gambar 13 sebaran wilayah banjir di kabupaten pacitan pada bulan November dan Desember 2017 mencakup wilayah kecamatan arjosari, ngadirojo, kebonagung dan pacitan. Berdasarkan Hasil overlay dengan peta daerah rawan banjir kabupaten pacitan didapatkan pada kecamatan arjosari wilayah yang terkena banjir
$21 \%$ merupakan wilayah dengan potensi yang tinggi dan sebagian besar berada di sepanjang daerah sungai. Desa yang terdampak banjir pada kecamatan arjosari yaitu desa sedayu, gayuhan, arjosari, gunungsari, gegeran, karangrejo, karanggede, dan jetis kidul.

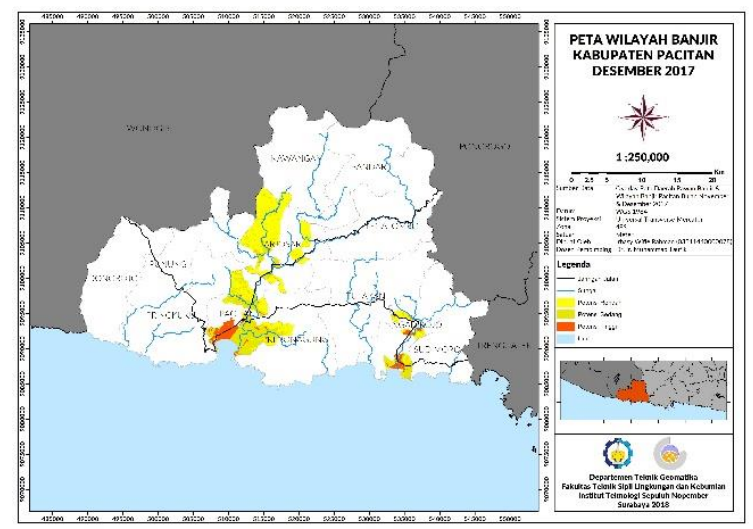

Gambar 13. Peta Wilayah Banjir Kabupaten Pacitan 2017

Pada kecamatan pacitan wilayah yang terkena banjir $74 \%$ merupakan wilayah dengan potensi yang tinggi dan berada di sepanjang daerah sungai dan pada kecamatan pacitan sebagian besar wilayahnya perupakan lahan terbangun. Desa yang terdampak Banjir pada kecamatan pacitan yaitu desa kayen, sukoharjo, arjowinangun, tanjungsari, ploso, sirnoboyo, kembang, widoro, semanten, ponggok, purworejo, sambong dan sidoharjo. Pada kecamatan kebonagung wilayah yang terkena banjir $36 \%$ merupakan wilayah dengan potensi yang tinggi dan berada di sepanjang daerah sungai. Desa yang terdampak banjir pada kecamatan kebongagung yaitu desa puwosari dan banjarjo. Pada kecamatan ngadirojo wilayah yang terkena banjir $73 \%$ merupakan wilayah dengan potensi yang tinggi dan berada di sepanjang daerah sungai. Desa yang terdampak banjir pada kecamatan ngadirojo yaitu desa bodag, hadiwarno, dan desa ngadirojo.

\section{KESIMPULAN}

Berdasarkan Pengolahan dan Analisis data yang dilakukan, penulis dapat mengambil kesimpulan dalam penelitian ini sebagai berikut :

a. Parameter penyusun daerah rawan banjir kabupaten pacitan yaitu parameter curah hujan, parameter kemiringan, parameter ketinggian, parameter tutupan lahan, 
parameter kerapatan aliran dan parameter jenis tanah.

b. Secara Matematis, hasil perhitungan bobot parameter penyebab banjir di kabupaten pacitan didapatka yaitu untuk parameter curah hujan sebesar 17,09; parameter kemiringan lereng sebesar 16,40; parameter ketinggian sebesar 16,58; parameter tutupan lahan sebesar 16,39; parameter kerapatan aliran sebesar 16,86 dan parameter jenis tanah sebesar 16,68.

c. Pembuatan Peta daerah rawan banjir di kabupaten pacitan menggunakan metode Multi-Criteria Evaluation (MCE) didapatkan hasil luas daerah rawan banjir yang dibagi menjadi 3 kelas, yaitu kelas tidak rawan dengan luas daerah 61.879 ha (44\%), kelas rawan dengan luas daerah 67.885 ha (48\%) dan kelas sangat rawan dengan luas daerah 11.144 ha $(8 \%)$.

\section{UCAPAN TERIMA KASIH}

Penulis mengucapkan terimakasih kepada Bapak Dr. Ir. Muhammad Taufik selaku dosen pembimbing yang telah memberikan dukungan dan bimbingan selama pengerjaan Penelitian ini dan Ibu Nanik Suryo Haryani selaku peneliti Pusat Pemanfaatan Penginderaan Jauh - LAPAN yang telah memberikan ilmu dan membantu kelancaran pengerjaan penelitian ini.

\section{DAFTAR PUSTAKA}

Amri, M. ., Yulianti, G., Yunus, R., Wiguna, S. (2016). RBI : Resiko Bencana Indonesia. Jakarta: BNPB.

BNPB. (217). Info Bencana : Informasi Kebencanaan BulananTeraktual, 7 December. Edisi November.

Suratijaya, I. N. (2007). Teknik Pemodelan dalam Pengolahan Alam dan Lingkungan. Bogor: Institut Petanian Bogor (IPB).

Haryani, N. S., A. Zubaidah, D. Dirgahayu, H. F. Yulianto, dan J. Pasaribu. (2012). Model Bahaya Banjir Menggunakan Data Penginderaan Jauh Di Kabupaten Sampang. Jurnal Penginderaan Jauh. No. 1. Vol. 9. Hal. 52-66. 